\title{
EDITORIAL
}

\section{Perlu Mendirikan Laboratorium Kesehatan Masyarakat Dalam Rangka Sustainable Development Goals For Healthy Future}

Perkembangan ilmu kedokteran dirumuskan dalam 4 tahap sebagai berikut: pertama, penyakit didiagnosis berdasarkan gejala-gejala dan tanda-tanda; kedua, dengan kemajuan mikrobiologi, diketahui penyebab penyakit, sehingga pengobatan penyakit didasarkan pada penyebab nya itu; ketiga, terjadi perkembangan ilmu kedokteran kearah spesialisasi sehingga penyakit tertentu ditangani secara kusus oleh para ahli yang bersangkutan; keempat, muncul kebutuhan terhadap apa yang disebut laboratorium kesehatan masyarakat, dimana dilakukan identifikasi masalah, apa penyebabnya, lalu melakukan pemecahan masalah tersebut atas dasar penyebab itu.

Perkembangan ilmu kedokteran seperti tersebut di atas mirip atau hampIr sejalan dengan evolusi epidemologi, melalui tahap-tahap sebagai berikut: pertama, zaman Mesir kuno; kedua, zaman Hippocrates disusul oleh Galen dan Fracostorius; ketiga, mulai abad ke 18, kemajuan epidemiologi karena munculnya teori miasma, kuantifikasi, masalah patologis historis geografis, penyelidikan lapangan, dan kemajuan mikrobiologi; keempat, muncul teori bahwa penyakit terjadi karena adanya interaksi antara faktor- faktor yang terdapat pada manusia dan lingkungannya sehingga penyakit bukan hanya disebabkan oleh agen yang infeksius, tetapi juga oleh agen yang non-infeksius.

Pada tahap ketiga evolusi epidemiologi waktu mana terjadi perkembangan mikrobiologi dengan mana ditemukan penyebab penyakit yang sesuai dengan tahap kedua dari perkembangan kedokteran. Pada tahap keempat dari evolusi epidemiologi waktu mana ditemukan bahwa penyakit disebabkan oleh agen yang infeksius dan agen yang non-infeksius, yang dalam tahap ketiga perkembangan ilmu kedokteran terjadi studi lebih mendalam dari berbagai penyebab penyakit sehingga mendalami spesialisasi dalam cabang ilmu kedokteran oleh para ahli yang bersangkutan.

Pada waktu-waktu selanjutnya baik evolusi epidemiologi ataupun perkembangan ilmu kedokteran, ternyata ilmu kedokteran memang cukup berhasil menyembuhkan penyakit, tetapi tidak dapat mengurangi masalah kesehatan. Ini demikian karena dipelopori oleh Blum yang menyatakan bahwa penyakit kusus nya dan masalah kesehatan umumnya disebabkan oleh faktor-faktor perilaku manusia, lingkungan, faktor biologi/genetika, dan pelayanan kesehatan, yang untuk mengidentifikasinya diperlukan metode epidemiologi. Faktor-faktor tersebut berbeda dari satu daerah dengan daerah yang lain, yang perlu dipelajari oleh berbagai disiplin ilmu dalam kesehatan masyarakat yang terkait dengan ilmu-ilmu lainnya yang tergabung dalam ilmu-ilmu sosial (behabioural sciences) yang terdiri atas sosiologi, antropologi dan psikologi. Karena itu dengan adanya Universitas yang mempunyai Fakultas Kesehatan Masyarakat dan fakultas ilmu kesehatan lainnya atau Sekolah Tinggi yang mempunyai Pogram Studi Ilmu Kesehatan Masyarakat dan Program Studi yang termasuk dalam ilmu ilmu kesehatan perlu bekerja sama dengan Dinas Kesehatan setempat dimana didirikan Laboratorium Kesehatan Masyarakat.

\section{Kenapa Perlu Kerjasama?}

Untuk menjawab kenapa perlu ada kerja sama antara Unibversitas dan Sekolah Tinggi dengan Dinas Kesehatan Kabupaten/Kota, maka diberikan satu contoh saja. Angka kelahiran di berbagai desa berbedabeda. Tetapi kalau diadakan survey dengan sampel yang representatif di tingkat nasional biasanya untuk angka kelahiran ditentukan presisi tertentu, misalnya 5 per 1000; bila dari hasil survey dalam sampel terdapat angka kelahiran 40 per 1000, maka angka kelahiran ini dalam populasi dalam bentuk interval yaitu 40 per $1000+/-5$ per $1000=35$ per $1000-45$ per 1000 . Angka kelahiran ini digunakan dalam rangka vaksinasi campak dan vaksinasi lain pada bayi. Atas dasar survey ini, Dinas Kesehatan Kabupaten memerintahkan ke puskesmas supaya setiap desa menghitung jumlah bayi atas dasar 40 per 1000 kelahiran setiap tahun. Misalnya jumlah penduduk desa 20.000, maka puskesmas menghitung bayi per tahun di desa itu $20.000 \times 40 / 1000=80$. Tetapi bidan di desa itu yang rutin mengumpulkan data kelahiran bayi hanya menemukan $70(35 / 1000 \times 20,000)$ bayi, sehingga 70 bayi itulah yang divaksinasi. Laporan ini disampaikan oleh Puskesmas ke Dinas Kesehatan Kabupaten (Dinkes Kab), namun laporan 70 yang divaksinasi tak dapat diterima oleh pejabat Dinkes $\mathrm{Kab}$, karena pejabat tersebut tak mengerti angka kelahiran tersebut dalam bentuk interval. Hal seperti ini mungkin terjadi dimana-mana di Indonesia. Pada saat ini ada beberapa paket pengolahan dan analisa data yang diciptakan di Kementerian Kesehatan (KemKes) dipraktekan di puskesmas. Dosen dan mahasiswa dari FKM atau STIKes sebetulnya perlu mempelajari perkembangan teknologi yang diciptakan dan dilaksanakan di Dinkes Kab atau Puskesmas, dengan maksud 1) apakah teknologi tersebut memang tepat secara akademis dan bermanfaat bagi fasilitas 
kesehatan dan masyarakat setempat; 2) bila tidak demikian, perlu ada pembahasan secara akademis antara pihak FKM/STIKes dengan pihak Dinkes $\mathrm{Kab} /$ Puskesmas untuk perbaikan teknologi tesebut, sehingga teknologi yang bersangkutan tidak hanya berguna di Dinkes yang bersangkutan tetapi juga di Dinkes Kab lain sebagai rujukan.

Dalam periode 15 tahun (2000-2015), di samping telah berdiri FKM dari berbagai Universitas telah berdiri pula setidaknya sekitar 160 STIKes di mana terdapat Program Studi Ilmu Kesehatan Masyarakat. FKM dan STIKes itu menghasilkan Sarjana Kesehatan Masyarakat setingkat S1, S2 dan S3. Tetapi masalah kesehatan tidak jelas menurun bahkan masalah beberapa penyakit meningkat. Banyak sekali skripsi, tesis dan disertasi yang telah dihasilkan, tetapi apakah informasinya sudah dapat berkontribusi untuk menyusun kebijakan dan membuat perencanaan? Salah satu faktor adalah faktor sosial budaya yang berbeda antara daerah. Karena itu informasi karya ilmiah dari lulusan tidak begitu saja dapat digunakan karena masing-masing mahasiswa melakukan pengumpulan data dari daerah-daerah dengan sosial ekonomi budaya yang berbeda-beda. Di samping itu masing-masing disiplin ilmu yang dikelola oleh bagian atau jurusan termasuk mahasiswanya dari Fakulatas Kesehatan Masyarakat hampir dapat dikatakan belum terintegrasi untuk menyelesaikan satu masalah kesehatan di suatu daerah misalnya kecamatan atau kabupaten. Cara pendidikan yang demikian menghasilkan lulusan bekerja di daerah nya tidak terintegrasi pula, bekerja sendiri-sendiri hanya sesuai dengan disiplin ilmu dalam kesehatan masyarakat yang diikutinya. Karena itulah pola pendidikan kesehatan masyarakat perlu dibangun dengan menggunakan laboratorium kesehatan masyarakat, dimana masingmasing disiplin ilmu secara terintegrasi dan terkordinasi secara bersama dapat menyelesaikan satu masalah tertentu. Bila calon dokter, perawat dan bidan di samping mendapat teori, sekaligus belajar praktek di rumah sakit dan puskesmas, seharusnya calon sarjana kesehatan masyarakat (S1, S2 dan S3) juga berlatih bekerja di Laboratorium Kesehatan Masyarakat, dimana mahasiswa dari berbagai disiplin ilmu dalam kesehatan masyarakat bekerja terintegrasi dan terkordinasi untuk memecahkan masalah kesehatan tertentu.

\section{The First IMOPH}

Pada tanggal 31 Oktober dan 1 November 2015, di Fakultas Kesehatan Masyarakat Universitas Indonesia (FKMUI) telah terjadi the First International Meeting of Public Health (IMOPH) 2015, yang dilaksanakan oleh mahasiswa Progam Pascasarjana FKMUI dengan mengundang para penulis dari seluruh Indonesia dan dari negara-negara ASEAN (South East Asia). Pada hari akhir pertemuan IMOPH yaitu pada tanggal 1 November 2015 telah terjadi kesepakatan antara wakil-wakil peserta dari beberapa universitas dan STIKes di Indonesia dan dari negara-negara ASEAN dengan menanda tangani petisi, bahwa pertemuan seperti ini untuk kedua kalinya akan diadakan lagi di FKMUI bulan November tahun 2016, dan tahun-tahun selanjutnya di negara-negara lain di ASEAN, bahkan mungkin di negara lain di Asia. Penghargaan pantas diberikan kepada Kelompok Mahasiswa Program Pascasarjana FKMUI sebagai pelopor untuk melaksanakan pertemuan internasional kesehatan masyarakat yang pertama dengan tema Sustainable Development Goals for Healthy Future, yang hasil akhirnya akan dapat dilihat 15 tahun lagi yaitu tahun 2030. Dalam hal ini tentu seluruh peserta institusi termasuk peserta yang ikut dalam pertemuan itu dan mewakili institusi itu harus mempunyai tanggung jawab dan semangat bagaimana mencapai development goals itu sesuai dengan target nya.

\section{MDG dan SDG}

Millenium Development Goals (MDG) yang harus mencapai targetnya dalam jangka waktu 2000 2015, menurut Atmawikarta (2015) dalam laporannya yang disampaikan dalam the first IMOPH, bahwa dari 63 indikator, hanya $13(21 \%)$ yang tercapai. Salah satu contoh indikator yang penting adalah Maternal Mortality Rate (MMR) yang semula rendah namun kemudian lebih tinggi mendekati tahun 2015, jadi target untuk MMR tidak tercapai. Kenapa tidak tercapai, ada yang mengatakan karena tak ada komitmen politik. Apa benar demikian menjadi pertanyaan, karena MDG langsung di bawah Presiden, dan kemudian didelegasikan kepada Prof. Dr. Nyla Moeloek, yang sekarang menjadi Menteri Kesehatan. Di samping itu sekretriat MDG dikelola dan dikordinir oleh BAPPENAS.

Mulai tahun 2016, SDG yang menggantikan MDG akan dilaksanakan. Dalam IMOPH pertama yang dilaksanakan di FKMUI yang mempunyai tema Sustainable Development Goals for Healthy Future, di mana hadir delegasi dari berbagai Universitas dan STIKes di Indonesia dan dari negara-negara ASEAN. Lalu seperti dinyatakan di atas, para akademisi dari universitas dan perguruan tinggi di Indonesia dan ASEAN telah menanda tangani petisi yang akan melanjutkan pertemuan IMOPH kedua tahun 2016. Yang menjadi pertanyaan apa peranan Universitas dan Perguruan Tinggi dalam rangka to achieve goals in $S D G$ for healthy future? Untuk menjawab pertanyaan ini, pembaca seharusnya sudah mengegetahui seperti yang telah dijelaskan di atas.

Walaupun kualitas dan akurasi data terjamin, hasil penelitian dari daerah lain yang berbeda soial ekonomi budaya dengan misalnya daerah A, maka hasil penelitian dari daerah lain itu untuk masalah yang sama tak dapat diterapkan begitu saja di daerah A. 
Karena itu Universitas atau Perguruan Tinggi kususnya dalam bidang kesehatan perlu melakukan penelitian atau studi yang terus menerus dan bekerjasama atau berkolabarasi dengan Dinas Kesehatan Kabupaten/Kota, dimana dibentuk Laboaratorium Kesehatan Masyarakat. Sesuai dengan SDG pada tingkat global, telah diadakan 1) persiapan untuk SDG, dimana dirumuskan 17 goals dan 252 indikator beserta target nya; dan 2) perumusan sistem nasional untuk mencapai goals, melalui integrasi SDG ke agenda pembangunan nasional dan subnasional dalam arti tingkat propinsi dan tingkat kabupaten/kota.

Dalam rangka pembangunan kesehatan yang merupakan komponen dari pembangunan semua sektor di tingkat kabupaten/kota, FKM atau STIKes di Laboratorium Kesehatan Masyarakat (LKM) melaksanakan pendidikan lapangan, pelatihan, pengabdian masyarakat dan penelitian yang dilakukan secara berkesinambungan mulai dari yang superfisial sampai kepada yang mendalam di wilayah setingkat kelurahan/desa, kecamatan dan kabupaten. Penelitian deskriptif yang relatif superfisial dilakukan oleh mahasiswa setingkat S1, penelitian analitik dilakukan oleh mahasiswa setingkat S2 yang relatif mendalam untuk pengembangan ilmu untuk menghasilkan karya inovatif, dan penelitian yang dilakukan oleh mahasiswa S3 dapat mengembangkan ilmu baru yang menghasilkan karya kreatif dan original. Di samping penelitian dilaksanakan pula surveilens yaitu kegiatan, pengolahan dan analisa data serta interpretasi informasi yang rutin dan terus menerus, yang dilaksanakan oleh mahasiswa setingkat S1 dan S2. Hasil penelitian deskriptif dapat digunakan untuk penelitian observasional analitik selanjutnya, sedangkan hasil penelitian observasional analitik, dapat digunakan untuk penelitian intervensi. Hasil penelitian dan surveilens dapat digunakan untuk perbaikan manajemen dan/atau penelitian analitik selanjutnya. Intervensi tersebut bersifat promotif, preventif dan kuratif yan terintegrasi atau kusus tersendiri yang diarahkan untuk peningkatan mutu pelayanan kesehatan masyarakat sehingga meningkatkan status kesehatan di wilayah yang bersangkutan.

Dalam perencanaan pelatihan, pendidikan lapangan, pengabdian masyarakat dan penelitian yang akan dilaksanakan oleh para mahasiswa, Direktur dan staf Laboratorium Kesehatan Masyarakat (LKM) berkordinasi dengan para dosen dari universitas dan sekolah tinggi yang bersangkutan. Disinilah akan adanya pertemuan antara para praktisi dari Kemkes, Dinas Kesehatan Kabupaten/Propinsi, dan Puskesmas dengan para akademikus dari universitas da sekolah tinggi yang mempunyai pengetahuan teoritis dan metodologis. Pertemuan ini diharapkan dapat memecahkan masalah yang selama ini mungkin ada karena kebijakan dari Kementerian Kesehatan (KemKes) tidak selalu cocok pelaksanaannya di tingkat puskesmas sehingga merugikan perencanaan dan pelaksanaan pelayanan kesehatan primer yang bersifat preventif dan promotif. Sekaligus di LKM ini dapat diuji apakah metodologi dan teori yang dari universitas dan sekolah tinggi yang dilaksanakan bermanfaat bagi peningkatan mutu pelayanan kesehatan primer, dan kalau tidak bermanfaat, para peneliti dirangsang supaya kreatif untuk menyempurnakan teori dan metodologi yang baru dengan memodifikasi teori dan metodologi lama atau menciptakan sesuatu yang baru.

\section{Rujukan}

Barton, W.L. 1971. Development of Health Services, Health Planning Course, yang dilaksanakan oleh Lenmbaga Kesehatan Nasional Surabaya, bulan Juli 1971 - 20 Agustus 1971.

Lapau, Buchari 2013. Prinsip dan Metode Epidemiologi, Jakarta: Badan Penerbit FKUI, Cetakan Keempat

Atmawikarta, Arum. 2015. Indonesian Perpective: Making Country More Sustainable to Live, a paper presented at the First International Meeting of Public Health (IMOPH), Faculty of Public Health UI, Depok Oct 31 - Nov 1, 2015.

(Buchari Lapau) 